\title{
Reactions of Substituted Xanthotoxin with Nitriles and Hydrazines
}

O. H. Hishmat*, A. H. Abd el Rahman**, A.-K. M. N. Gohar***, and M. H. Abdel-Rahman*

* National Research Centre, Dokki, Cairo, Egypt

** Faculty of Science, Mansoura University, Mansoura, Egypt

*** Faculty of Sciene, El-Minia University, Minia, Egypt

Z. Naturforsch. 34b, 1154-1158 (1979); received February 28, 1979

Substituted Xanthotoxin

4-Bromoxanthotoxin reacts with cyanoacetamide to form 4-bromo-5,6-dihydroxanthotoxin, which on hydrolysis with cold hydrochloric acid leads to the formation of cyanoacetic acid derivative, but hydrolysis by boiled hydrochloric acid gives the acetic acid derivative.

Thio-, and 4-nitroxanthotoxin reacts with malononitrile in presence of piperidine by addition to give thio- and 4-nitro-5,6-dihydroxanthotoxin-5-[1',3',3'-tricyano-2-aminopropene-(2)] respectively, while in presence of ammonia leads to the formation of 5 malononitrile derivatives.

The reaction of hydrazine and phenyl hydrazine with thio- and 4-bromothioxanthotoxin leads to the formation of the hydrazones.

Also thio- and 4-bromothioxanthotoxin reacts with anhydrous aluminium chloride in benzene by cleavage of the furan ring and the formation of 6 -(1,2-diphenylethyl)-7,8dihydroxythiocoumarin and 5-bromo-6-(1,2-diphenylethyl)-7,8-dihydroxythiocoumarin, respectively.

Because of the wide spread and increasing interest in xanthotoxin (9-methoxy-7 H-furo[3,2-g][1]benzopyran-7-one) for its pharmacological action [1-3], this study was undertaken to investigate some of the chemical properties of the compound and to prepare new derivatives for biological testing.

In this study the reactions of substituted xanthotoxin: 4:bromo- (1), thio- (1b), and 4-nitroxanthotoxin $(\mathbf{1}$ c) $[4,5]$, (which were prepared by bromination, thionation and nitration of xanthotoxin), with cyanoacetamide and malononitrile under different condition were investigated.

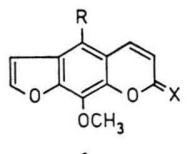

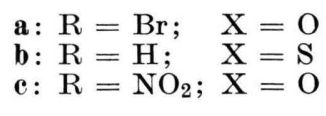

1

Thus, whereas 4-bromoxanthotoxin (4-bromo-9methoxy-7H-furo[3,2-g][1]benzopyran-7-one) (1 a) reacted with cyanoacetamide in presence of piperidine by adding to the double bond of the pyrone ring to form 5,6-dihydro-4-bromoxanthotoxin-5cyanoacetamide $(\mathbf{2} \mathbf{a})$.

The structure of $\mathbf{2 a}$ has been confirmed by its infrared spectrum, which shows characteristic bands at 1165 and $1055 \mathrm{~cm}^{-1}$ due to the in-plane bending vibrations of the $\alpha$ - and $\beta$-hydrogen atoms of the

* Reprint requests to Dr. O. H. Hishmat. 0340-5087/79/0800-1154/\$01.00/0

furan ring [6]. The strong peak at $1750 \mathrm{~cm}^{-1}$ is characteristic of an $\alpha, \beta$-unsaturated- $\delta$-lactone [7]. The amide I band occurs at $1645 \mathrm{~cm}^{-1}$, while amide II appeared at $1635 \mathrm{~cm}^{-1}$. The stretching vibration at $2255 \mathrm{~cm}^{-1}$ shows the presence of $\mathrm{C} \equiv \mathrm{N}$ group (saturated alkyl nitrile) [8]<smiles></smiles>

2

$$
\begin{array}{ll}
\text { a: } \mathrm{R}=\mathrm{CN} ; & \mathrm{R}^{\prime}=\mathrm{NH}_{2} \\
\text { b: } \mathrm{R}=\mathrm{CN} ; & \mathrm{R}^{\prime}=\mathrm{OH} \\
\text { c: } \mathrm{R}=\mathrm{H} ; & \mathrm{R}^{\prime}=\mathrm{OH}
\end{array}
$$

Hydrolysis of $\mathbf{2 a}$ with cold hydrochloric acid leads to the formation of 4-bromo-5,6-dihydroxanthotoxin-5-cyanoacetic acid ( $2 \mathrm{~b})$, while hydrolysis with boiling hydrochloric acid gave 4-bromo-5,6-dihydroxanthotoxin-5-acetic acid (2c).

The infrared spectra of $\mathbf{2} \mathbf{c}$ and $\mathbf{2} \mathbf{b}$ show bands at 1740 and $1745 \mathrm{~cm}^{-1}$ characteristic for $-\mathrm{COOH}$ group.

In a similar manner thioxanthotoxin $(\mathbf{l} \mathbf{b})$ reacts also by addition with cyanoacetamide to give 5,6dihydrothioxanthotoxin-5-cyanoacetamide (3).<smiles></smiles>

3

Malononitrile reacts with thioxanthotoxin $(\mathbf{1} b)$ and 4-nitroxanthotoxin (1 $\mathrm{c})$ in presence of piperidine to form thio- (4a) and 4-nitroxanthotoxin-5$\left[1^{\prime}, 3^{\prime}, 3^{\prime}\right.$-tricyano-2-aminopropene $\left.(2)\right](4 \mathrm{~b})$, respec- 
tively, probably by dimerization of malononitrile in alkaline medium to form 5 which then adds to the double bond of the pyrone ring.

The infrared spectra of $4 \mathrm{a}$ and $4 \mathrm{~b}$ reveals the presence of $\mathrm{C} \equiv \mathrm{N}$ group $\left(2235\right.$, and $\left.2230 \mathrm{~cm}^{-1}\right)$. Bands at 1645 and $1635 \mathrm{~cm}^{-1}$ characteristic for $-\mathrm{NH}$ of $\mathrm{NH}_{2}$ group stretching respectively.

The asymmetric and symmetric $\mathrm{N}-\mathrm{H}$ stretching mode for the compounds $4 \mathrm{a}$ and $4 \mathrm{~b}$ appears at 3365 and $3350 \mathrm{~cm}^{-1}$ and 3295 and $3290 \mathrm{~cm}^{-1}$, respectively. Also compound 4 a shows a band at $1740 \mathrm{~cm}^{-1}$ (the carbonyl group of the lactone ring) and $4 \mathrm{~b}$ shows bands at $1120 \mathrm{~cm}^{-1}(>\mathrm{C}=\mathrm{S})$.
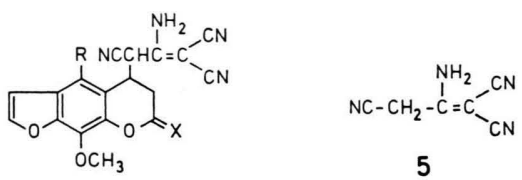

4

$\mathbf{a}: \mathrm{R}=\mathrm{H} ; \quad \mathrm{X}=\mathrm{S}$

b: $\mathrm{R}=\mathrm{NO}_{2} ; \mathrm{X}=\mathrm{O}$

Alkaline hydrolysis of $4 \mathrm{a}$ and $4 \mathrm{~b}$ leads to opening of the pyrone ring and formation of the acides $\mathbf{6 a}$ and $6 \mathrm{~b}$, respectively.<smiles></smiles>

6

In this investigation the reaction of 4 -bromo(1 a), thio- (1 b), and 4-nitroxanthotoxin (1 c) with malononitrile in presence of ammonia gave the malononitrile derivatives $7 \mathbf{a}, \mathbf{7 b}$, and $\mathbf{7} \mathbf{c}$, respectively.<smiles>[X]C1=Cc2c(c(OC)c3occc3c2[R])CC1C(C)N</smiles>

a: $\mathrm{R}=\mathrm{Br} ; \quad \mathrm{X}=\mathrm{O}$

b: $\mathrm{R}=\mathrm{H} ; \quad \mathrm{X}=\mathrm{S}$

c: $\mathrm{R}=\mathrm{NO}_{2} ; \mathrm{X}=\mathrm{O}$

7

It have been shown that the lactone ring of xanthotoxin was opened by the action of hydrazine hydrata and gave 6-hydroxy-7-methoxy-5-benzofuranacrylic acid hydrazide [5]. In this investigation the reaction of thio- (1 b) and 4-bromothioxanthotoxin (8) with hydrazine hydrate and phenyl hydrazine in ethanol led to the condensation of the hydrazines on the thiocarbonyl group and gave the hydrazones $9 \mathrm{a}, 9 \mathrm{~b}, 9 \mathrm{c}$, and $9 \mathrm{~d}$ respectively.
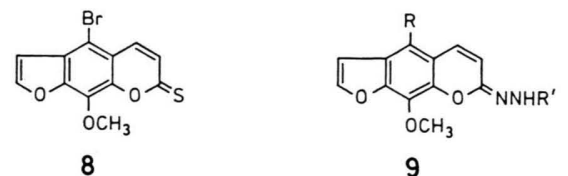

a: $\mathrm{R}=\mathrm{R}^{\prime}=\mathrm{H}$

b: $\mathrm{R}=\mathrm{Br} ; \quad \mathrm{R}^{\prime}=\mathrm{H}$

c: $\mathrm{R}=\mathrm{H} ; \quad \mathrm{R}^{\prime}=\mathrm{C}_{6} \mathrm{H}_{5}$

d: $\mathrm{R}=\mathrm{Br} ; \quad \mathrm{R}^{\prime}=\mathrm{C}_{6} \mathrm{H}_{5}$

The infrared spectra of $9 \mathrm{a}, \mathbf{9 b}, \mathbf{9 c}$, and $9 \mathrm{~d}$ shows the absence of $-\mathrm{OH}$ and $=\mathrm{C}=\mathrm{O}$ groups and shows bands at $1633,1640,1635$, and $1630 \mathrm{~cm}^{-1}$ respectively, characteristic for $-\mathrm{C}=\mathrm{N}$ groups, also these compounds gave no colour with equeous ferric chloride solution.

When $\mathbf{1 b}$ and 8 were treated with aluminium chloride in benzene, cleavage of the furan moity occured with simultaneous addition of two moles of benzene to produce 6-(1,2-diphenylethyl)-7,8dihydroxythiocoumarin (10a) and 5-bromo-6-(1,2diphenylethyl)-7,8-dihydroxythiocoumarin (10 b) respectively.

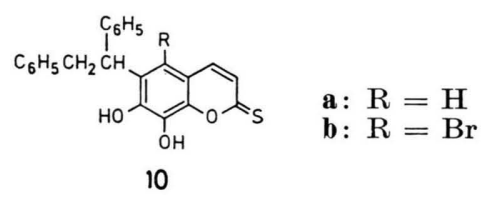

The infrared spectra of both compounds 10a and $10 \mathrm{~b}$ shows the presence of $-\mathrm{OH}$ group as a broad band (3280-3100 and $\left.3170-3070 \mathrm{~cm}^{-1}\right)$.

\section{Experimental}

Melting points were not corrected. PMR were obtained at $60 \mathrm{MHz}$ in $\mathrm{CDCl}_{3}$ or TFA, with TMS as internal standard. Mass Spectra were run at $70 \mathrm{eV}$. the infra-red were carried out in potassium bromide on a Unicam infrared spectrophotometer Model SP 1000.

\section{Preparation of 5,6-dihydro-4-bromoxanthotoxin-} 5-cyanoacetamide (2a)

A mixture of $2 \mathrm{~g}$ of 4-bromoxanthotoxin (1 a) and $1 \mathrm{~g}$ of cyanoacetamide in $25 \mathrm{ml}$ ethanol and piperidine (l ml) was refluxed for $6 \mathrm{~h}$ (crystallization started while hot), leave to cool. Filter the solid that separated and crystallize from chloroform as colourless crystals, m.p. $292{ }^{\circ} \mathrm{C}$ with decomposition (yield is $c a .80 \%$ ). It is soluble in dilute sodium hydroxide solution. 
Analysis for $\mathrm{C}_{15} \mathrm{H}_{11} \mathrm{BrO}_{5} \mathrm{~N}_{2}$ (379)

Calcd C 47,49 H 2.90 Br 21.11 N 7.39,

Found C 47.62 H 3.03 Br 21.35 N 7.57.

PMR [9] (TFA) $\delta 4.50 \mathrm{~s}\left(3 \mathrm{H}, \mathrm{OCH}_{3}\right), 3.4 \mathrm{~m}(4 \mathrm{H}$, aliphatic), $703 \mathrm{~d}(1 \mathrm{H}, J=2 \mathrm{~Hz}, \mathrm{C}-3)$, and $7.70 \mathrm{~d}$ $(1 \mathrm{H}, J=2 \mathrm{~Hz}, \mathrm{C}-2)$. Low resolution MS, $m / e \mathrm{M}^{+}$ $379(40), 377(40), 363(27), 361(29), 309(100)$, and $299(20)$.

\section{5,6-Dihydro-4-bromoxanthotoxin-5-cyanoacetic acid $(\mathbf{2} \mathbf{b})$}

A mixture of 5,6-dihydro-4-bromoxanthotoxin5-cyanoacetamide (2a) $(0.7 \mathrm{~g})$ and $8 \mathrm{ml}$ of cold concentrated hydrochloric acid was vigerously shaken for $4 \mathrm{~h}$, then left at room temperature overnight. Filter the solid and crystallize from acetone as colourless crystals, m.p. $275{ }^{\circ} \mathrm{C}$; yield is $c a .67 \%$. It dissolves in aqueous sodium hydroxide to form a yellow colouration, it is also soluble in sodium bicarbonate solution.

Analysis for $\mathrm{C}_{15} \mathrm{H}_{10} \mathrm{BrNO}_{6}$ (380)

Calcd $\quad \mathrm{C} 47.37 \quad \mathrm{H} 2.63 \quad \mathrm{~N} 3.68 \quad \mathrm{Br} 21.05$,

Found C 47.21 H 2.42 N 3.83 Br 20.85.

PMR (TFA) $\delta 3.45 \mathrm{~m}(4 \mathrm{H}$, aliphatic), $4.43 \mathrm{~s}(3 \mathrm{H}$, $\left.\mathrm{OCH}_{3}\right), 6.98 \mathrm{~d}(1 \mathrm{H}, J=2 \mathrm{~Hz}, \mathrm{C}-3)$ and $7.85 \mathrm{~d}(1 \mathrm{H}$, $J=2 \mathrm{~Hz}, \mathrm{C}-2)$. MS m/e M+ $380(100), 356(98)$, $354(15), 337(27), 323(17), 300(22)$, and $296(38)$.

\section{5,6-Dihydro-4-bromoxanthotoxin-5-acetic acid (2c)}

$0.5 \mathrm{~g}$ of $1 \mathrm{a}$ was refluxed with $8 \mathrm{ml}$ of concentrated hydrochloric acid for $2 \mathrm{~h}$, then left to cool. Filter the precipitate and wash with $n$-hexane, crystallize the solid from dilute ethanol as deep yellow crystals, m.p. $170^{\circ} \mathrm{C}$ with decomposition (yield is $c a .80 \%$ ). It is soluble in sodium bicarbonate solution and in sodium hydroxide solution.

Analysis for $\mathrm{C}_{14} \mathrm{H}_{11} \mathrm{BrO}_{6}$ (355)

$\begin{array}{lllll}\text { Calcd } & \text { C } 47.32 & \text { H } 3.10 & \text { Br 22.54, } \\ \text { Found } & \text { C } 47.01 & \text { H } 3.25 & \text { Br 22.63. }\end{array}$

PMR (TFA) $\delta 3.43 \mathrm{~m}(5 \mathrm{H}$, aliphatic), $4.40 \mathrm{~s}(3 \mathrm{H}$, $\left.\mathrm{OCH}_{3}\right), 6.90 \mathrm{~d}(1 \mathrm{H}, J=2 \mathrm{~Hz}, \mathrm{C}-3)$, and $7.80 \mathrm{~d}(1 \mathrm{H}$, $J=2 \mathrm{~Hz}, \mathrm{C}-2)$. MS m/e M+ 355(100), 337(33), $322(31), 295(50)$, and $280(25)$.

\section{5,6-Dihydrothioxanthotoxin-5-cyanoacetamide (3)}

As in case of $\mathbf{2 a}, 2 \mathrm{~g}$ of thioxanthotoxin $(\mathbf{1} \mathbf{b})$ and $1 \mathrm{~g}$ of cyanoacetamide in $25 \mathrm{ml}$ of ethanol and piperidine $(1 \mathrm{ml})$, gave $55 \%$ of 3 as deep yellow crystals m.p. $283{ }^{\circ} \mathrm{C}$ with decomposition from chloroform. It is soluble in sodium hydroxide solution.

Analysis for $\mathrm{C}_{15} \mathrm{H}_{12} \mathrm{O}_{4} \mathrm{~N}_{2} \mathrm{~S}$ (316)

$\begin{array}{lllll}\text { Calcd } & \text { C } 56.96 & \text { H } 3.80 & \text { N } 8.86 & \text { S 10.13, } \\ \text { Found } & \text { C } 57.31 & \text { H 3.91 } & \text { N 8.57 } & \text { S 10.42. }\end{array}$
Preparation of 5,6-dihydrothioxanthotoxin-5-

$\left[1^{\prime}, 3^{\prime}, 3^{\prime}\right.$-tricyano-2'-aminopropene(2)] (4a)

A mixture of $2 \mathrm{~g}$ of thioxanthotoxin $(\mathbf{1} \mathbf{b})$ and $3 \mathrm{ml}$ of molononitrile in $25 \mathrm{ml}$ of ethanol and few drops of piperidine was refluxed for one hour, then left to cool filter the solid that obtained and crystallize from acetone as deep orange crystals, m. p. $>300^{\circ} \mathrm{C}$; yield is $c a .80 \%$.

Analysis for $\mathrm{C}_{18} \mathrm{H}_{12} \mathrm{O}_{3} \mathrm{~N}_{4} \mathrm{~S}$ (364)

$\begin{array}{lllll}\text { Calcd } & \text { C } 59.34 & \text { H } 3.30 & \text { N } 15.38 & \text { S 8.79, } \\ \text { Found } & \text { C 59.55 } & \text { H 3.08 } & \text { N 15.22 } & \text { S 9.01. }\end{array}$

5,6-Dihydro-4-nitroxanthotoxin-5-

[1',3',3'-tricyano-2'-aminopropene-(2)] (4b)

In a similar manner $2 \mathrm{~g}$ of 4-nitroxanthotoxin (1 c) and $3 \mathrm{ml}$ of malononitrile in $25 \mathrm{ml}$ ethanol and few drops of piperidine, led to the formation of $\mathbf{4 b}$ as brown crystals from acetone, m.p. $255{ }^{\circ} \mathrm{C}$ with decomposition; yield is $c a .60 \%$.

Analysis for $\mathrm{C}_{18} \mathrm{H}_{11} \mathrm{O}_{6} \mathrm{~N}_{5}$ (393)

$\begin{array}{lllll}\text { Calcd } & \text { C 54.96 } & \text { H } 2.80 & \text { N 17.81, } \\ \text { Found } & \text { C 54.73 } & \text { H } 3.01 & \text { N 17.93. }\end{array}$

Hydrolysis of $\mathbf{4} \mathbf{a}$ with sodium hydroxide solution (6a)

$0.3 \mathrm{~g}$ of $4 \mathrm{a}$ was refluxed with $3 \mathrm{ml}$ of $10 \%$ sodium hydroxide solution for one hour, cool then dilute with water $(10 \mathrm{ml})$ and neutralize with acetic acid. Filter the solit that separated and crystallize from ethanol to give the known compound [10] as colourless crystals (mixed m.p. gave no depression); yield is ca. $40 \%$.

Hydrolysis of $\mathbf{4} \mathbf{b}$ with sodium hydroxide solution $(\mathbf{6 a})$

In a similar manner as in case of 5 a $1 \mathrm{~g}$ of $4 \mathrm{~b}$ when refluxed with $10 \mathrm{ml}$ of $10 \%$ sodium hydroxide solution led to the formation of $\mathbf{6} \mathbf{b}$, from acetone as yellow crystals, m.p. $>300{ }^{\circ} \mathrm{C}$; yield is $c a .45 \%$.

Analysis for $\mathrm{C}_{18} \mathrm{H}_{13} \mathrm{~N}_{5} \mathrm{O}_{7}$ (411)

Calcd C 52.55 N 3.16 N 17.03,

Found C 52.83 N 3.22 N 16.86 .

\section{Preparation of 5,6-dihydro-4-bromoxanthotoxin-}

5-malononitrile (7a)

A mixture of $3 \mathrm{~g}$ of 4-bromoxanthotoxin (1 a) and $3 \mathrm{ml}$ of malononitrile in $24 \mathrm{ml}$ ammonia was refluxed for $1 / 2 \mathrm{~h}$, cooled, the solid filtered, washed with hot benzene and crystallize from ethanol and few drops of acetone as colourless crystals, m.p. $270^{\circ} \mathrm{C}$; yield is $\mathrm{ca} .90 \%$.

Analysis for $\mathrm{C}_{15} \mathrm{H}_{9} \mathrm{BrN}_{2} \mathrm{O}_{4}$ (361)

Calcd C 49.86 H 2.49 Br 22.16 N 7.76,

Found $\quad$ C 50.12 H 2.65 $\quad$ Br 22.33 N 7.95.

\section{5,6-Dihydrothioxanthotoxin-5-malononitrile (7b)}

In a similar manner as in case of $\mathbf{7} \mathbf{a}$, a mixture of $3 \mathrm{~g}$ of thioxanthotoxin (1 b) and $3 \mathrm{ml}$ of malono- 
nitrile gave $85 \%$ of $7 \mathbf{b}$ as orange crystals from acetone, m.p. $242{ }^{\circ} \mathrm{C}$.

Analysis for $\mathrm{C}_{15} \mathrm{H}_{10} \mathrm{~N}_{2} \mathrm{O}_{3} \mathrm{~S}$ (298)

$\begin{array}{lllll}\text { Calcd } & \text { C } 60.40 & \text { H } 3.36 & \text { N } 9.39 & \text { S } 10.74, \\ \text { Found } & \text { C } 60.11 & \text { H } 3.52 & \text { N } 9.64 & \text { S } 11.03 .\end{array}$

5,6-Dihydro-4-nitroxanthotoxin-5-malononitrile (7e)

$3 \mathrm{~g}$ of $\mathbf{1 c}$ and $3 \mathrm{ml}$ of malononitrile in benzene furnished $82 \%$ of 5,6-dihydro-4-nitroxanthotoxin5 -malononitrile $(\mathbf{7} \mathrm{e})$ as yellow crystals from acetone, m.p. $232{ }^{\circ} \mathrm{C}$.

Analysis for $\mathrm{C}_{15} \mathrm{H}_{9} \mathrm{~N}_{3} \mathrm{O}_{6}$ (327)

Calcd C 55.05 H 2.75 N 12.84,

Found C 54.83 H $2.93 \quad \mathrm{~N} 13.03$.

\section{Preparation of xanthotoxin-7-hydrazone (9a)}

$1 \mathrm{~g}$ of $\mathbf{1 b}$ and $0.9 \mathrm{ml}$ of hydrazine hydrate was refluxed for $24 \mathrm{~h}$ in $50 \mathrm{ml}$ of $95 \%$ ethanol. The solution was diluted with water and cooled. The product was collected and crystallized from petrol ether (b.p. $60-80{ }^{\circ} \mathrm{C}$ ), m.p. $135{ }^{\circ} \mathrm{C}$; yield is ca. $70 \%$. It gave no colour with ferric chloride solution.

Analysis for $\mathrm{C}_{12} \mathrm{H}_{10} \mathrm{~N}_{2} \mathrm{O}_{3}$ (230)

Calcd C 62.61 H 4.44 N 12.17,

Found C 62.43 H 4.57 N 11.98 .

PMR $\left(\mathrm{CDCl}_{3}\right), \delta 0.83 \mathrm{~s}\left(2 \mathrm{H}, \mathrm{NH}_{2}\right), 4.33 \mathrm{~s}(3 \mathrm{H}$, $\left.\mathrm{OCH}_{3}\right), 7.75 \mathrm{~d}(1 \mathrm{H}, J=2 \mathrm{~Hz}, \mathrm{C}-2), 6.71 \mathrm{~d}(1 \mathrm{H}$, $J=2 \mathrm{~Hz}, \mathrm{C}-3), 7.00 \mathrm{~d}(1 \mathrm{H}, J=10 \mathrm{~Hz}, \mathrm{C}-5)$ and $6.58 \mathrm{~d}(1 \mathrm{H}, J=10 \mathrm{~Hz}, \mathrm{C}-6)$. MS $m / e \mathrm{M}^{+}, 230(100)$, $214(40), 215(40)$, and 286(50).

\section{Preparation of 4-bromoxanthotoxin-7-hydrazone (9b)}

As in case of $9 \mathrm{a}$, a mixture of $1 \mathrm{~g}$ of 4-bromoxanthotoxin (1a) and $0.9 \mathrm{ml}$ of hydrazine hydrate in ethanol gave a yellow crystals of $\mathbf{9 b}$ from petrol ether (b.p. $60-80{ }^{\circ} \mathrm{C}$ ), m.p. $117{ }^{\circ} \mathrm{C}$; yield is $c a .68 \%$. Analysis for $\mathrm{C}_{12} \mathrm{H}_{9} \mathrm{BrN}_{2} \mathrm{O}_{3}$ (309)

Calcd $\quad \mathrm{C} 46.60 \quad \mathrm{H} 2.91 \quad \mathrm{Br} 25.89$ N 9.06, Found $\quad$ C 46.96 $\quad$ H 3.07 $\quad$ Br 26.23 N 9.18.

\section{Preparation of xanthotoxin-7-phenylhydrazone (9c)}

A mixture of $1 \mathrm{~g}$ of thioxanthotoxin $(\mathbf{l} \mathbf{b})$ and $0.8 \mathrm{ml}$ of phenylhydrazine in $50 \mathrm{ml}$ of ethanol was refluxed for $24 \mathrm{~h}$, diluted with water, left to cool and filtered. The product was collected and recrystallized from ethanol as orange crystals, m.p. $133^{\circ} \mathrm{C}$; yield is $c a .63 \%$.

Analysis for $\mathrm{C}_{18} \mathrm{H}_{14} \mathrm{~N}_{2} \mathrm{O}_{3}$ (306)

Calcd C 70.59 H 4.90 N 9.15,

Found C 70.84 H 5.01 N 8.93.
PMR $\left(\mathrm{CDCl}_{3}\right), \delta 7.20 \mathrm{~s}(5 \mathrm{H}$, aromatic), $7.46 \mathrm{~d}(1 \mathrm{H}$, $J=2 \mathrm{~Hz}, \mathrm{C}-2), 6.64 \mathrm{~d}(1 \mathrm{H}, J=2 \mathrm{~Hz}, \mathrm{C}-3), 6.76 \mathrm{~d}$ $(1 \mathrm{H}, J=10 \mathrm{~Hz}, \mathrm{C}-5), 6.16 \mathrm{~d}(1 \mathrm{H}, J=10 \mathrm{~Hz}, \mathrm{C}-6)$, and $7.20 \mathrm{~s}(1 \mathrm{H}, \mathrm{NH})$. MS $m / e \mathrm{M}^{+}, 306(100), 214(60)$, $201(80), 225(60)$, and $170(40)$.

\section{4-Bromoxanthotoxin-7-phenylhydrazone (9d)}

$1 \mathrm{~g}$ of 8 and $0.9 \mathrm{ml}$ of phenylhydrazine in ethanol gave $83 \%$ of $9 \mathrm{~d}$ as yellow crystals, m.p. $1700^{\circ} \mathrm{C}$ in $73 \%$ yield. It gave no colour with aqueous ferric chloride solution.

\section{Analysis for $\mathrm{C}_{18} \mathrm{H}_{13} \mathrm{BrN}_{2} \mathrm{O}_{3}$ (385)}

Calcd $\quad$ C 56.10 H 3.37 Br 20.78 N 7.27,

Found $\quad$ C 56.23 H 3.42 Br 20.41 N 7.54.

PMR $\left(\mathrm{CDCl}_{3}\right) \delta 7.21 \mathrm{~s}(5 \mathrm{H}$, aromatic $), 7.16 \mathrm{~d}(1 \mathrm{H}$, $J=2 \mathrm{~Hz}, \mathrm{C}-2), 6.76 \mathrm{~d}(1 \mathrm{H}, J=2 \mathrm{~Hz}, \mathrm{C}-3), 6.92 \mathrm{~d}$ $(1 \mathrm{H}, J=10 \mathrm{~Hz}, \mathrm{C}-5), 6.37 \mathrm{~d}(1 \mathrm{H}, J=10 \mathrm{~Hz}, \mathrm{C}-6)$, and $7.85 \mathrm{~s}(1 \mathrm{H}, \mathrm{NH})$. MS $m / e \mathrm{M}^{+}, 385(80), 354(40)$, $331(70), 293(60)$, and $281(100)$.

\section{6-(1,2-Diphenylethyl)-7,8-dihydroxythio- coumarin (10a)}

A mixture of $1 \mathrm{~g}$ of thioxanthoxin $(\mathbf{1} \mathbf{b})$ and $2 \mathrm{~g}$ of anhydrous aluminium chloride in $100 \mathrm{ml}$ of dry benzene was refluxed for $30 \mathrm{~min}$. The benzene was decanted and evaporated to dryness. The residue was acidified and recrystallized from ethanol, yield is ca. $65 \%$; m.p. $212{ }^{\circ} \mathrm{C}$. It gave a greenish brown colour with aqueous ferric chloride solution.

Analysis for $\mathrm{C}_{24} \mathrm{H}_{20} \mathrm{O}_{3} \mathrm{~S}$ (388)

Calcd C 74.22 H 5.15 S 8.24,

Found C 74.51 H 5.43 S 8.41.

\section{5-Bromo-6-(1,2-diphenylethyl)-7,8-dihydroxythio- coumarin $(\mathbf{1 0 b})$}

As in case of $10 \mathrm{a} 1 \mathrm{~g}$ of 4-bromothioxanthotoxin (8) and $2 \mathrm{~g}$ of anhydrous aluminium chloride in benzene gave $70 \%$ of 5 -bromo-6-(1,2-diphenylethyl)-7,8-dihydroxythiocoumarin (10 b) as brown crystals from ethanol, m.p. $195{ }^{\circ} \mathrm{C}$; yield is $c a .83 \%$. It gave a green colour with aqueous ferric chloride solution.

Analysis for $\mathrm{C}_{24} \mathrm{H}_{19} \mathrm{BrO}_{3} \mathrm{~S}$ (467)

$\begin{array}{lllll}\text { Calcd } & \text { C 61.67 } & \text { H 4.07 } & \text { Br 17.13 } & \text { S 6.85, } \\ \text { Found } & \text { C 61.93 } & \text { H 4.23 } & \text { Br 17.21 } & \text { S 7.01. }\end{array}$

PMR $\left(\mathrm{CDCl}_{3}\right), \delta 3.65 \mathrm{~m}(3 \mathrm{H}$, aliphatic) and $7.13 \mathrm{~s}$ (12 H, aromatic). MS m/e $\mathrm{M}^{+}, 467(10), 465(40)$, $374(68)$, and $287(100)$. 
[1] A. Schönberg and N. Latif, J. Am. Chem. Soc. 76, 6208 (1954).

[2] A. Elwi, J. Roy. Egypt. Med. Assoc. 33, 773 (1950).

[3] I. Fahmy and H. Abu-Shady, Quart. J. Pharm. Pharmcol. 21, 499 (1948).

[4] H. Thomas and E. Baetck, Ber. 45, 3705 (1912).

[5] M. E. Brokke and B. E. Christenson, J. Org. Chem. 23, 589 (1958).

[6] W. W. Epstein, W. J. Horton, and C. T. Lin, J. Org. Chem. 30, 1246 (1965).
[7] R. N. Jones and F. Herling, J. Org. Chem. 19, 1252 (1954).

[8] L. J. Bellamy, The Infra-red Spectra of Complex Molecules, Methuen and Co. Ltd., London 1958.

[9] High Resolution NMR Spectra Catalog by Varian Associate, 1962, U.S.A. and R. Silverstein, G. Clayton, and T. C. Morril, Spectrometric Identification of Organic Compounds, 3rd Edition, John Wiley and Sons, Inc. New York 1974.

[10] O. H. Hishmat and A.-K. M. N. Gohar, Indian J. Chem. 14 B, 747 (1976). 